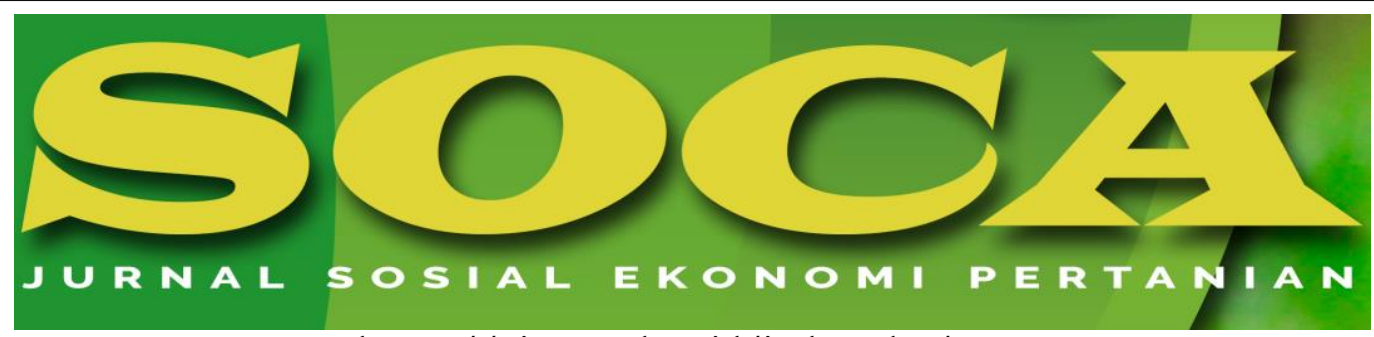

https://ojs.unud.ac.id/index.php/soca

\title{
Analysis of Chicken Meat Supply Chain in Dua Putra Perkasa Pratama Company (Inc.)
}

Annisa Maulina Wardhani, Titik Ekowati and Wiludjeng Roessali

Agricultural Department, Faculty of Agriculture and Animal Husbandry, Diponegoro University Email: annisa.mwardhani@gmail.com

Handphone: 083877253784

Submitted: February 18th, 2020; Revised: March 19th, 2020; Accepted: April 7th, 2020

\begin{tabular}{ll}
\hline Keywords: & Abstract \\
flow; chicken & Supply chain analysis required in the entire business process \\
meat; working & because it produced a more sufficient product on the producer \\
performance; & amount of product. This study purpose was to analyze the main \\
mechanism; & product flow, mechanism, and supply chain performance of the \\
supply chain & chicken meat produced by the Dua Putra Perkasa Pratama \\
\hline & Company (Inc.) The study location was chosen by a purposive \\
& sampling technique, while the participant selection done by \\
& judgment sampling technique. The participants were the \\
& supplier, key informant from the company, and customer. The \\
& supply chain, mechanism, and performance data analyzed by \\
& descriptive analysis method with the Supply Chain Operations \\
& Reference (SCOR) model. Results showed that the flow of the \\
& supply chain, financial supply chain, and informational was \\
& moving from the upstream to downstream, downstream to \\
& upstream, and upstream to downstream or downstream to \\
& upstream, respectively. The company supply chain performance \\
classified in a very good range performance with a total score of \\
96.73.
\end{tabular}

How to Cite (APA $6^{\text {th }}$ Style):

Wardhani, A. M., Ekowati, T., \& Roessali, W. (2020). Analysis of Chicken Meat Supply Chain in Dua Putra Perkasa Pratama Company ( Inc .). SOCA: Jurnal Sosial Ekonomi Pertanian, 14(3), 424-432.

https://doi.org/https://doi.org/10.24843/SOCA.2020.v14.i03.p04 


\section{INTRODUCTION}

Animal husbandry has a high chance to be developed as an agribusiness entity in the future. Chicken meat is one type of meat that massively demanded by the community to meet their daily nutrition need. Chicken meat rich in animal protein and contains complete essential amino acids and lower fat compared to other types of meat (Susanto, 2003). The rapid growth of the population contributed to the higher number of chicken meat demand. Therefore, the availability of chicken meat expected to stay stable to meet the population demand.

According to the previous study done by (Purwaningasih, Arief, \& Rahmawati, 2016), a chicken agribusiness supply chain consisted of five closely related subsystems: upstream agribusiness, cultivation subsystem, processing subsystem, marketing subsystem, and supporting subsystem.

Dua Putra Perkasa Pratama Company (Inc.) was the biggest meat distributor in Indonesia. This company sold various types of meat products, one of them was chicken meat product. The company's sale potential was very high, but there was no supply chain effectivity evaluation done yet. The competitive tension between the company that moves on the same field was getting tighter, consequently the efficient management in the chicken meat product sale must be improved.

The supply chain analysis produced a more sufficient chicken meat product on the producer to the consumer level with the precise condition, time, and amount of meat product. This study aimed to analyze the main product flow, mechanism, and supply chain performance of the chicken meat produced by Dua Putra Perkasa Pratama Company (Inc). This study expected to contribute as a reference that explained the supply chain performance for the company, hence the company could take proper decisions to maintain their stability and generate better products.

\section{RESEARCH METHODS}

This study conducted in November to December 2019 in Dua Putra Perkasa Pratama Cipendawa Bekasi Company (Inc.). This study location chosen by purposive sampling technique due to some reasons: (1) biggest chicken meat distributor company and (2) the high quality and variety of the chicken meat produced.

This was a case study employing the judgment sampling technique in the participant selection process. The participant in this study were supplier (chicken slaughterhouse) key informant from the company, and customer from the processed food industry, modern market, and restaurant. The key informant from the company who participated were the poultry manager, finance manager, logistic advisor, logistic supervisor, poultry supervisor, and human resources development staff. The data collection method used were interview, observation, and documentation. The primary and secondary data collected were analyzed using descriptive quantitative and qualitative methods. The method used to analyze the product supply chain mechanism was the descriptive analysis method done by identifying the four supply chain elements (network structure, business process, management, and supply chain resource) prior to the analysis process (Vorst, 2005). The method used to analyze the supply chain performance were:

I. Level Identification on the Supply Chain Operations Reference (SCOR) Model SCOR has three hierarchy processes that revealed the decomposition process from the general to the specific aspect (Pujawan, 2017). 
II. Identification and Determination of the Key Performance Indicator (KPI) and Analytical Hierarchy Process (AHP).

The KPI identification was done based on the interview and pairwise comparison questionnaire results. The result then used to determine the weight of each attribute in each matrix level that had arranged and analyzed according to the performance of the company (Saaty, 2001). It processed by the software expert choice version 2000.

III. Supply Chain Performance Calculation

The supply chain performance analysis calculation done by using the formula of: company actual value: company targeted value $\mathrm{x}$ AHP weight. The result classified based on the criteria of the performance value standard stated by (Monczka, Handfield, and Patterson, 2011) that specifically illustrated in Table 1. According to this analysis, some inadequate indicators implementation also could be identified and analyzed.

\section{RESULT AND DISCUSSION Main Flow}

The chicken meat supply chain main flow in Dua Putra Perkasa Pratama Company (Inc.) consisted of product, financial, and information flow which illustrated by Figure 1.

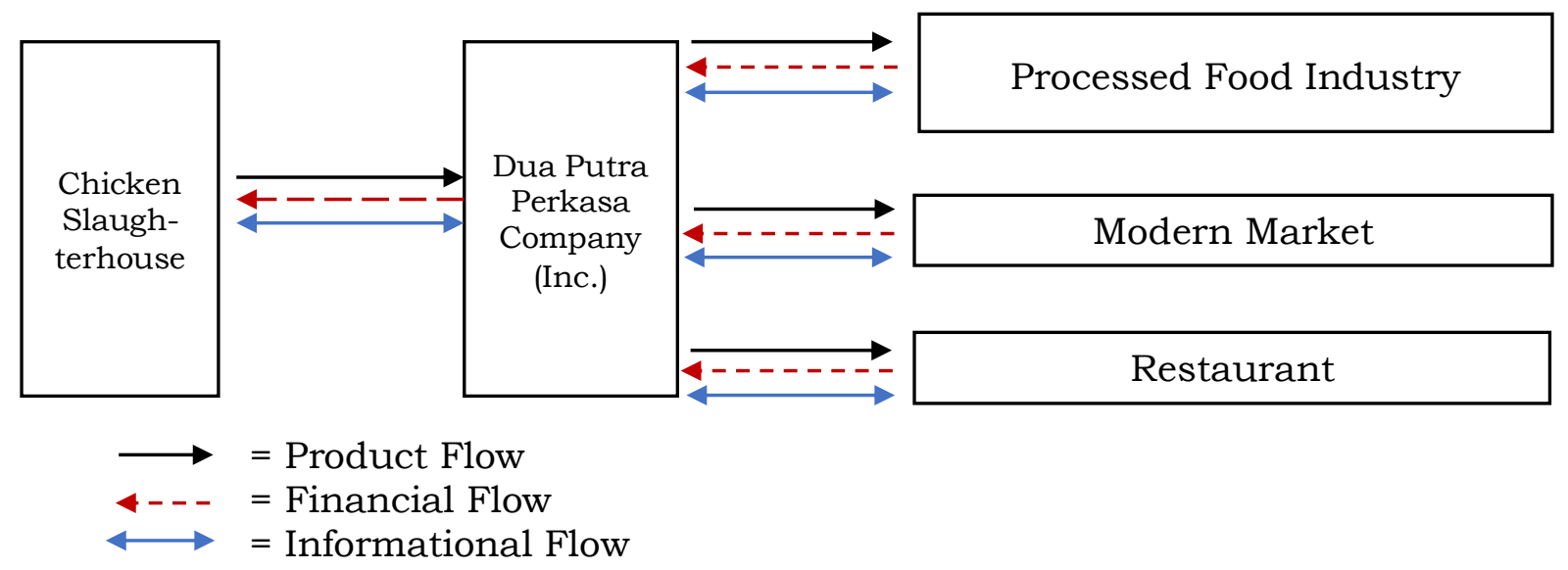

Figure 1. The chicken meat supply chain main flow in Dua Putra Perkasa Pratama Company (Inc.)

1. Product Flow

The chicken meat product flow in Dua Putra Perkasa Pratama Company (Inc.) was moving from the upstream to the downstream. This was parallel with the Yuniar (2012) that stated the commodity flowed from the upstream (producer) to downstream (consumer). The product flow pattern in this company was from the slaughterhouse, the company, and end on the processed food industry, modern market, and restaurant.

2. Financial Flow

The chicken meat product financial flow started from the consumer and end on the supplier or slaughterhouse. This was parallel with Widisatriani, Widyantara, \& Angreni, 2015 that stated financial was flowing from the downstream to the upstream or from consumer to the producer. There were some types of consumers 
in this supply chain: the processed food industry, the modern market, and restaurant. The type of payment used in this company were deposit (20-30\%), cash on delivery (COD), and time ranged payment (in 7 days, 30 days, or 45 days).

3. Information Flow

The informational flow in this company happened in two way manner, from the downstream to the upstream or from the upstream to the downstream. This was parallel with the Yuniar (2012) that stated informational flow happened in twoway, from the downstream to the upstream or from the upstream to the downstream. The informational flow between the supply chain participant related to the product stock, price, variation, quality, quantity, and payment method in the selling or buying activity.

\section{Supply Chain Participant}

The participant played a closely related role in the supply chain. Well performed role was important in assuring the optimal cycle in the supply chain. Each role of the participant explained below:

a. Supplier

The supplier was the first participant in the supply chain (upstream. Supplier played its role in the procurement of the chicken meat product. Taylor (2009) stated that in the upstream supply chain, the supplier was the one that prepared the product and distributed it. Sinaga (2011) also stated that the upstream supply chain consisted of activities done by the company and the distributor with other partners. The chicken meat supplier for this company was the chicken slaughterhouse. The selection of this meat supplier done according to the modern chicken slaughterhouse standard quality, veterinary control number certificate, food safety management certificate, good manufacture practice, halal certificate, the fresh quality of the meat, affordable price, and their capability in meeting the company demand. There were 20 suppliers in this company, but only six suppliers (Berdikari (limited partnership), Kasih Karkasindo Utama (limited partnership), Sido Raya Utama (limited partnership), Windhu Boga Pratama (limited partnership), Wahana Sejahtera Food (limited partnership) and Tri Putra Panganindo (Inc.)) routinely supplied chicken meat to this company.

b. Dua Putra Perkasa Pratama Company (Inc.)

Dua Putra Perkasa Pratama Company (Inc.) played as an internal supply chain that consisted of product acceptance, repacking, product storage in the warehouse, product movement, and product distribution. This was similar to Sinaga (2011) that stated the internal supply chain consisted of the product storage in the warehouse, its distribution, and until the product exit the organization. This company had implemented a quality management system according to ISO standard since the year of 2014.

c. Customer

The customer was the last part of the supply chain or the supply chain downstream. The customer was the buyer of the chicken meat product in this company. There were three types of customer in the Dua Putra Perkasa Pratama Company (Inc.): processed food industry, modern market, and restaurant (with a total of more than 15 customers). The processed food industry customers were 
Champs Indonesia Company (Inc.) and Belfoods Indonesia Company (Inc.). The modern market customers were Trans Retail (Carrefour), Supra Boga Lestari (Farmers Market), Matahari Putra Prima (Hypermart), Lottemart Indonesia (Lottemart), Lion Super Indo (Superindo), and Akur Pratama (Jogja Supermarket). While the restaurant customers were Sari Kencana (Pizza Hut), Sriboga Marugame Indonesia (Marugame), Sari Rasa Nusantara (Sate Khas Senayan), Sushi Tei Company (Sushi Tei), Bavarian Culinary, Citrarasa Prima, Reska Multi Usaha, Shabu Yoi, and Makro Prima Pangan Utama (Cimory).

\section{Product}

Dua Putra Perkasa Pratama Company (Inc.) distributed various types of meat products, but according to the study, we focused the discussion on the chicken meat product. The type of chicken meat sold in this company were pure fat, whole-size chicken (4-14), breast fillet, chicken wing, Hainan chicken, upper thigh part, lower thigh part, boneless breast, boneless skin thighs, boneless breast fillet, chicken meat trimming, MDM chicken, chicken skin, chicken head, esophagus, chicken gizzard and chicken liver. All chicken meat products could be last for one year. The capacity of the chicken meat product in the storage was $0.2 \mathrm{~kg} / \mathrm{sack}$. The best temperature in the storage area was ranged between -18 to $-25^{\circ} \mathrm{C}$. Cold storage must be located in an area with a maximum room temperature of $20^{\circ} \mathrm{C}$ (National, 1999). The quality of chicken meat sold by this company classified in the first quality (thick, in a perfect and intact form, free from bruised and feather). The chicken meat sold in this company met the modern chicken slaughterhouse standard quality, veterinary control number certificate, food safety management certificate, good manufacture practice, and halal certificate.

\section{Supply Chain Management}

The contract system involving all the supply chain participants. This was similar to the statement of Shabrina (2015) that defined a contract system as a intensive coordination done according to the policies agreed by the involved parties. The written agreement used in this company listed the specific part of chicken meat's sale policies. Chicken meat products that required specific written agreement (in a memorandum of understanding (MoU)) were the skin, thigh, wing, and boneless part. Another part of chicken criteria (fast-moving part) did not list on that agreement.

This company used the First in First Out (FIFO) and Fresh Expired First Out (FEFO) method as the expenditure flow management. FIFO was a method done by selling the first product accepted by the company. FIFO implemented to maintain the quality of the chicken meat product and improving customer satisfaction. While FEFO was a method done by selling the product with the closest expired date. This method produced lower losses both on the seller and buyer parties. FEFO method was not applicable for delivery service in the area distant from the company due to the short expired date. This was parallel with the Rahma (2010) that stated the product with a close expired date must be sold first, although it was accepted before the other product.

The stock and inventory control routinely conducted in Dua Putra Perkasa Pratama Company (Inc.). Stock and inventory control done to maintain the accuracy of chicken meat stock in the warehouse. Stock control done once a year, especially 
during the holiday before Eid Al-Fitr in a lane of warehouses based on the data on the warehouse management system (WMS). Inventory control activity is done every day in a warehouse or one lane warehouses.

\section{Market}

The market demand for chicken meat product relatively increased in each month due to the high consumption of chicken meat and the improvement of the food microsmall-medium enterprises in Indonesia. The supply and sale usually increase one month before the fasting period until the fasting period end or during the Christmas and new year holiday. The chicken meat demand and sale significantly decreased during the school-holiday season or Eid al-Adha celebration.

\section{Human Resources}

The Dua Putra Perkasa Pratama Company (Inc.) employed 205 staff with the level of educational background varied from the junior high school to university. The company operational hours were Monday to Friday, from 08.00 to 17.00 and Saturday from 08.00 to 15.00 . The company's staff annually trained on some technical aspects such as food safety, food security, Good Manufacturing Practice (GMP), fire extinguisher used, Hazard Analysis and Critical Control Points (HACCP), sanitation, product handling, delivery, warehouse, and occupational health and safety).

\section{The Business Process}

The business process on each unit in the company observed based on the pushpull concept. Basu (2017) stated that push-process happened as the consumer anticipation, while the pull process happened due to the consumer demand. The push process happened due to the forecast (customer request anticipation) that done by implementing the buffer stock system, while the pull process was happened due to the consumer request. The business process on the supplier unit was a pull process because the chicken meat supply provided based on the company demand.

\section{Supply Chain Performance}

The performance measure revealed the information needed to repair and develop the supply chain management in the company. The AHP analysis on the supply chain criteria shown in Table 1. 
Table 1. Evaluation of Chicken Meat Product Supply Chain in Dua Putra Perkasa Pratama Company (Inc.)

\begin{tabular}{|c|c|c|c|c|}
\hline Criteria & $\begin{array}{c}\text { Targeted Metric } \\
\text { Value } \\
--\%--\end{array}$ & $\begin{array}{c}\text { Actual Metric } \\
\text { Value } \\
--\%--\end{array}$ & $\begin{array}{c}\text { AHP } \\
\text { Weight }\end{array}$ & $\begin{array}{l}\text { Performance } \\
\text { Score }\end{array}$ \\
\hline $\begin{array}{l}\text { Supplier Accuracy in } \\
\text { Sending the Product }\end{array}$ & 100 & 85 & 0.075 & 6.38 \\
\hline $\begin{array}{l}\text { Product Quality and } \\
\text { Freshness }\end{array}$ & 100 & 90 & 0.074 & 6.66 \\
\hline $\begin{array}{l}\text { Product Availability } \\
\text { Accuracy }\end{array}$ & 100 & 95 & 0.122 & 11.59 \\
\hline Production Capacity & 100 & 98 & 0.073 & 7.15 \\
\hline Production Planning & 80 & 90 & 0.096 & 10.80 \\
\hline $\begin{array}{l}\text { Availability of } \\
\text { Product to be } \\
\text { Produced }\end{array}$ & 100 & 85 & 0.076 & 6.46 \\
\hline Request Execution & 100 & 95 & 0.068 & 6.46 \\
\hline $\begin{array}{l}\text { Reception of } \\
\text { Customer Request }\end{array}$ & 100 & 95 & 0.082 & 7.79 \\
\hline $\begin{array}{l}\text { Request and Product } \\
\text { Compatibility }\end{array}$ & 100 & 98 & 0.096 & 9.41 \\
\hline $\begin{array}{l}\text { Sale Return Handling } \\
\text { Method }\end{array}$ & 100 & 100 & 0.065 & 6.50 \\
\hline $\begin{array}{l}\text { Production and } \\
\text { Procurement Cost }\end{array}$ & 50 & 45 & 0.067 & 6.03 \\
\hline $\begin{array}{l}\text { Product Shipping } \\
\text { Cost }\end{array}$ & 10 & 8 & 0.065 & 5.20 \\
\hline Sale Return Cost & 10 & 15 & 0.042 & 6.30 \\
\hline Total & & & & 96.73 \\
\hline
\end{tabular}

Source: Processed Primary Data (2019). 
Table 2 showed that the chicken meat product supply chain categorized in a very good range of performance with a total of 96.73. The accuracy of the chicken meat product prediction (product availability accuracy) was the main alternative strategy in the supply chain with a total weight of 11.59 . The product shipping cost weighted 5.20. This indicated that this strategy was not significant in the supply chain due to the expectation of an inexpensive price to send the product. The high weight score on the product availability accuracy strategy was very beneficial in maintaining the sale activity and meeting the customer request. Higher accuracy resulted in a higher ability in meeting customer product demand. The low weight obtained by the product shipping cost was also accurate due to high availability accuracy would contribute to the lower possibility of mistake in sending the product, therefore the shipping cost would get cheaper.

\section{CONCLUSION}

According to the study result, we concluded that the chicken meat product supply chain was moving from the chicken slaughterhouse to the customer (processed food customer, modern market, and restaurant). The financial and informational flow was moving from the customer to the slaughterhouse and from the customer to the slaughterhouse or from the slaughterhouse to the customer (twoway flow), respectively. The company supply chain classified in a very good range performance with a total score of 96.73 .

\section{RECOMMENDATION}

We suggest the company to conduct a supply chain performance evaluation to comprehensively understand and evaluate the performance of the chicken meat product supply chain. The quality control of the chicken meat product also required to be improved in preventing the product sales return.

\section{REFERENCES}

Basu. (2017). Managing Global Supply Chains. New York: Routledge.

Monczka., Handfield dan Patterson, J. (2011). Purchasing and Supply Chain Management. Canada: Joe Sabatino.

Nasional, B. S. (1999). Persyaratan Rumah Pemotongan Unggas. Jakarta: Standard Nasional Indonesia.

Pujawan., M. (2017). Suppy Chain Management. Yogyakarta: Andi.

Purwaningasih, R., Arief, M., \& Rahmawati, D. (2016). Analisis Rantai Pasok dan Distribusi Ayam Pedaging. 176-183.

Rahma. (2010). Strategi Dahsyat Marketing Mix for Small Business. Jakarta: Transmedia.

Saaty. (2001). Decesion Making for Liaders. University of Dittsburgh: RWS publication.

Shabrina, N. (2015). No Title. Strategi Peningkatan Rantai Nilai Agroindustri Daging Sapi, (Tesis). 
Sinaga, B. B. (2011). Analisis Sistem Rantai Pasok Pt. Semen Gresik (Persero) Tbk. Jurnal Optimasi Sistem Industri. https://doi.org/10.25077/josi.v10.n1.p105112.2011

Susanto. (2003). Ayam Goreng Tradisional Indonesia. Jakarta: PT. Gramedia Pustaka.

Taylor., R. (2009). Operantions Management. Singapore: Wiley.

Vorst. (2005). Perfomanca Measurement in Agro Food Suply Chain Networks. Netherlands: Springer.

Widisatriani, G., Widyantara, I., \& Angreni, I. (2015). Manajemen Rantai Pasok Benih Cabai Rawit (Kasus di Yayasan Idep, Desa Batuan Kaler, Kecamatan Sukawati, Kabupaten Gianyar). E-Journal Agribisnis Dan Agrowisata (Journal of Agribusiness and Agritourism).

Yuniar. (2012). Analisis manajemen rantai pasok bunga melati di Kabupaten Karanganyar. Tesis Magister Agribisnis Universitas Sebelas Maret. 